\title{
Technical Evaluation of Community Based Soil and Water Conservation Structures: A Case Study in Damot Gale Woreda, Wolayita Zone, South Ethiopia
}

\author{
Haimanot Zewdu ${ }^{1, ~ *}$, Awdenegest Moges ${ }^{2}$, Feto Esimo ${ }^{3}$, Dulo Husen ${ }^{4}$ \\ ${ }^{1}$ Southern Nations Nationalities and Peoples Regional State Water, Mines and Energy Development Bureau, Hawasa, Ethiopia \\ ${ }^{2}$ Biosystems and Environmental Engineering Department, Hawassa University, Hawassa, Ethiopia \\ ${ }^{3}$ Ethiopian Institute of Agricultural Research, Addis Ababa, Ethiopia \\ ${ }^{4}$ Oromia Agricultural Research Institute, Adami Tulu Agricultural Research Center, Batu, Ethiopia
}

Email address:

haimanotzewudu@gmail.com (H. Zewdu)

${ }^{*}$ Corresponding author

\section{To cite this article:}

Haimanot Zewdu, Awdenegest Moges, Feto Esimo, Dulo Husen. Technical Evaluation of Community Based Soil and Water Conservation Structures: A Case Study in Damot Gale Woreda, Wolayita Zone, South Ethiopia. International Journal of Science, Technology and Society. Vol. 9, No. 5, 2021, pp. 245-255. doi: 10.11648/j.ijsts.20210905.17

Received: May 12, 2021; Accepted: October 13, 2021; Published: October 30, 2021

\begin{abstract}
In Arujya and Bilbo watershed, soil erosion is one of the series causes of soil degradation. The aim of this study was to technical evaluation of physical SWC measures constructed during the 2007 E.C campaign on cultivated field and implementation approaches in SWC development campaign and to analyze land use and land cover change. The data were collected through field measurements and satellite image download from NASA website. The selected physical soil and water conservation measures in both watersheds were level soil bund and level fanyajuu. For fanyajuu technical evaluation of the structures showed that generally in Bilbo watershed ditch depth, ditch width and spacing at 10-15\% slope class and in Arujya watersheds ditch width and bottom width of embankment were lower than the recommended one and spacing at $15-30 \%$ slope higher than recommended. For soil bund, the technical evaluation ditch depth was in both watershed and ditch width in Bilbo was smaller than recommended and spacing in both watersheds wider than recommended value. In Bilbo watershed, forest coverage increased by $11.22 \%$ from 1987 to 2010 . Grass land coverage decreased by $4.76 \%$ between 1987 and 2010 and then increased from 2010 to 2015. In Arujya watershed forest coverage was decreased by $0.46 \%$ from 1987 to 2010 . Shrub and bush land cover decreased by $0.41 \%$ between 1987 and 2010. Cultivated land increased by $3.4 \%$ between 2010 and 2015. Similarly, forest land decreased by $0.13 \%$ in 2010 . In the same period, the rate of shrubs and bushes decreased by $2.58 \%$ from 2015 to 2010. Technical evaluation needs some improvement in the design, community participation in planning phase and land cover changes shows affected cultivated land and vegetation cover through the population increment. It recommended that the future development activities will be used these technologies more for better management of the natural resources in watershed.
\end{abstract}

Keywords: Land Covers Change, Land Use, Level Soil Bund, Level Fanyajuu, Community Participation

\section{Introduction}

Intensive soil and water conservation activities since more than three decades ago, adoption of the interventions in Ethiopia is considerably rather low. This fact is frequently attributed, among other things, to the top-down approach in extension activities, standard mainly structural soil and water conservation technologies, lack of awareness of land degradation by the land users, and land security issues. To tackle these devastating facts of soil erosion problems, the issue of soil management has emanated since 1970 s in Ethiopia. A massive soil conservation and rehabilitation of degraded lands was executed through soil and water conservation program. However, the continuous assessments and evaluations made on the system identified many drawbacks of the soil and water conservation program. Solomon [8] summarized some of the drawbacks of the program as over emphasis on structural measures for 
erosion control on cultivated slopes, uniform application of measures regardless of variations in agro-ecological situations, over dependent on "food-for-work" programs, safety net program and MERET program to carry out the soil conservation activities. In recent decades, soil and water conservations have been implemented based on watershed level in Ethiopia. The government of Ethiopia plan to cover around 7 million hectare of land using the Soil Conservation works through community mobilization effort in four major regions (MoA, 2010.).

Wolayita highlands are one of severely threatened high lands in the country. It believed that it comes to occur widely after expansion of crop production from the flat to sloping land with inappropriate land use and management practices. This indicated some of the factors causing decline of soil fertility as clearing of forests, the removal of crop residues from the fields, land fragmentation, reduction of fallows, overgrazing, low fertilizer inputs, inadequate soil and water conservation measures, cropping of marginal lands and poor soil management [3]. An implication for soil degradation is that land cover change is one of the factors that determine the rate of soil loss due to erosion [10]. In addition, in many places, there exist variation between the area specific technical criteria of the physical soil and water conservation measure. In fact, the SWC practices are recommended to a given area based on the slopeand participation regarding all the dimensions. Now a day's in Damot Gale Woreda Non-governmental organization and
Government have struggling to prevent inappropriate agricultural expansions to this fragile watershed. However, the processes and output have not been systematically studied and evaluation has been made so far in the study area to understand technical parameter and land use and land cover change and how they react this problem to cope up from its consequence, the study to explore the technical evaluation of physical situations. The objectives of this study is to evaluate the performance of community based soil and water conservation activities in Bilbo and Arujya sub-watersheds and determine the change in land use and land cover in sample watersheds using Remote sensing image from three different period.

\section{Materials and Methods}

\subsection{Description of the Study Area}

The study was carried out in Wolayita zone Damot Gale woreda, which is located in escapement of rift valley and lies between $6.89^{\circ}-7.12^{\circ} \mathrm{N}$ and $37.75^{\circ}-38^{\circ} \mathrm{E}$ longitude. The altitude ranges from 1900-3000 meters above sea level and its peak was Mount Damot and $370 \mathrm{~km}$ of South of Addis Ababa and is $150 \mathrm{~km}$ West of Hawassa city, the capital city of the Southern Nations Nationalities and Peoples Regional State (SNNPRS). The woreda has area coverage of 24,285.9 ha and accommodates an estimated number of 145,741 human populations.

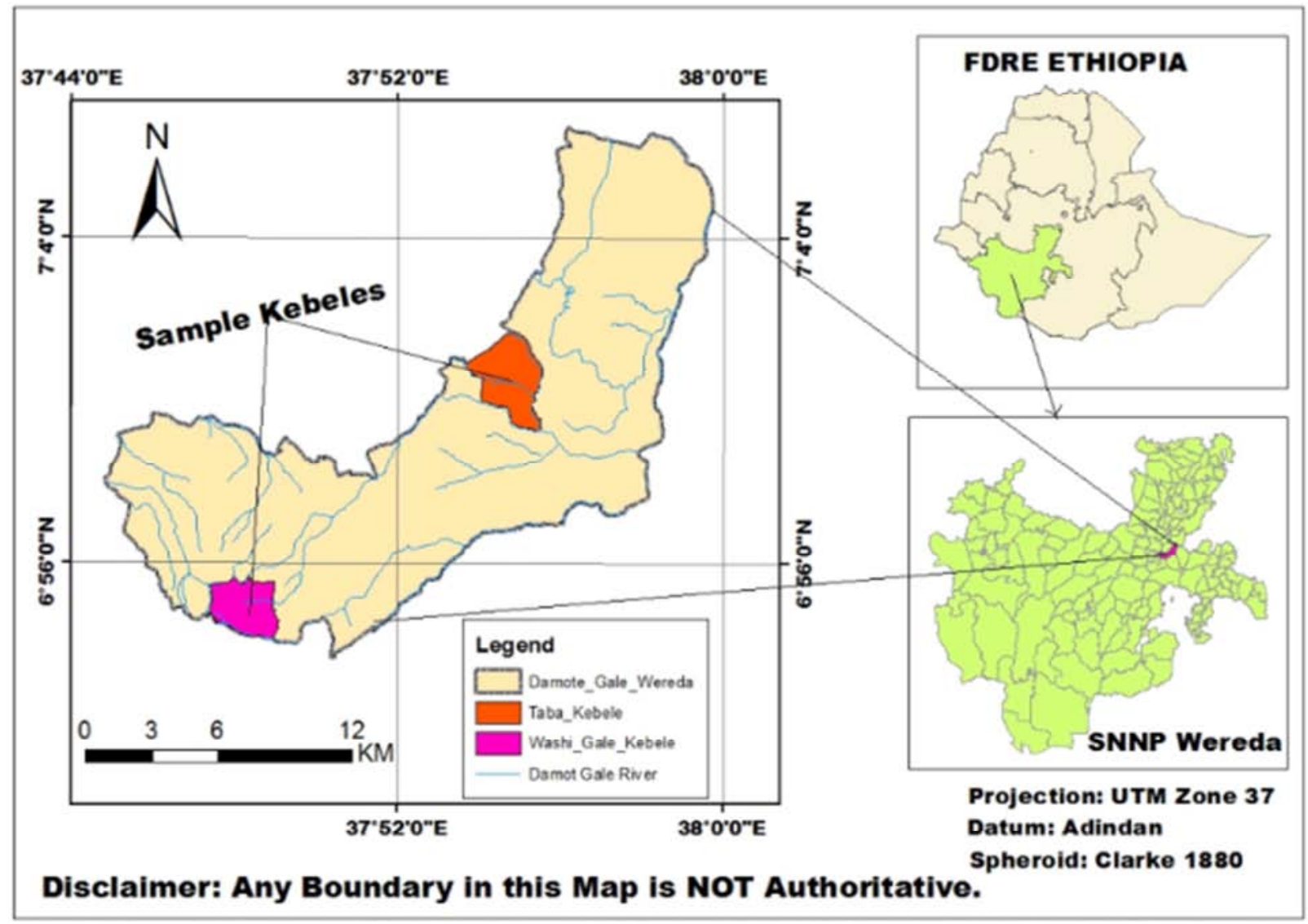

Figure 1. Map of Damot Gale woreda (source: CSA, 2015). 


\subsection{Climate and Topography}

Two cropping seasons (called Gabbaa and Silla in local or Belg and Meher in national language, respectively) known in the area. The Belg cropping season extends from March to May with medium amount of rainfall, whereas Meher extends from June to September with high amount of rainfall. Mean annual rainfall was $1328.4 \mathrm{~mm}$ with the highest record in August. Damot Gale district have Dega (22\%), Woyna Dega (49\%) and Derke Woyna Dega (29\%) climatic condition. The mean annual minimum and maximum temperature of the area were $10.8^{\circ} \mathrm{C}$ to $28^{\circ} \mathrm{C}$ respectively. The topography of Demote Dale woreda is ranged from middle to steep slope. The mount Damota is rugged with deep gorges incised by river valleys. The slope gentle at its foot but becomes very steep at about altitude of $2000 \mathrm{~m}$ and above.

\subsection{Soil and Land Use Type}

Soil types in Damot Gale district are silt, clay and clay loam. In mount Damota area, the soil has reddish brown (Nitosols) color and derived from a multistory ignimbrite substratum the soil has high porosity and infiltration [9]. These features gave the soil a good quality for cultivation. However, low levels of nitrogen and phosphorus (nutrient depletion) due to erosion and repeated cultivation significantly affect the production in the area [7]. There are different land use types in Damot Gale district which include perennial crops, annual crops, forest, grazing land and others such as fallow land. Intensification of cultivation is higher in the district.

\subsection{Data Collection}

\subsubsection{Site Selection and Sampling Techniques}

From Damot Gale woreda, Peasant Associations (PAs) were purposively selected based on Woreda Agricultural experts and researcher. Two Peasant Associations (Woshi gale and Taba) were selected purposively from Damot Gale Woreda based on the performance of SWC and the watershed were selected from each Peasant Associations based on 2015 soil and water conservation participation.

The slope category of the study area was measured using clinometers. According to the collected data; the study area were classified in to three slope classes classes $(<5 \%, 5-10 \%$, $10-15,15-30 \%$ and $>30 \%$ ). Technical parameters of soil bund and fanyajuu were evaluated under those slope classifications from sub watersheds. Bilbo watershed classified into three slope classes $(<5 \%, 5-10 \%$ and $10-15 \%)$ and Arujya watershed were classified into $5 \mathrm{sub}$ watershed $(<5 \%, 5-10 \%$, $10-15 \%, 15-30 \%$ and $>30 \%$ ). The field plots for each SWC measures in three slope classes have three replicate for measurement of the technical aspects (design) of soil and water conservation measures. The sample watersheds were assessed to determine the land use/land cover change resulted due to the SWC measures applied using remote sensing imagery.

\subsubsection{Technical Evaluation of Physical Soil and Water Conservation Measures}

Field measurement was made on soil bund and fanya juu on cultivated land at selected plot. An expert from the district agricultural office, development agent and the researcher were participated in the measurement of soil bund and fanyaajuu structures. Field measurement was done for each selected structure using measuring tape (depth and width of ditch, top and bottom width of the embankment, height of the embankment, soil depth and berm of the structure) were measured. Technical design parameters were done for SWC structures at three terrains at the $>30 \%, 15-30 \%$ and $<15 \%$ $(<5 \%, 5-10 \%$ and $10-15 \%)$ of the sampled plots. Each sampled plots was divided in to three slope section $(<15 \%)$ as replicate on Bilbo micro-watershed and five slope section as replicate in Arujya watershed.

\subsection{Land Use and Land Cover Change}

Land use and land cover used to track the rate and extent of land rehabilitation and degradation change due to implementation of soil and water conservation measures in the sample watersheds. Landsat 8 satellite images with $30 \mathrm{~m}$ and $15 \mathrm{~m}$ resolution and captured frequently per year were available free download on NASA web site and was used for the study. Landsatellite image data taken in 1987 before soil and water conservation, in 2010 year and 2015 after soil and water conservation intervention in the area. The satellite image data was analyzed to examine and predict the land use/land cover change in the study watersheds.

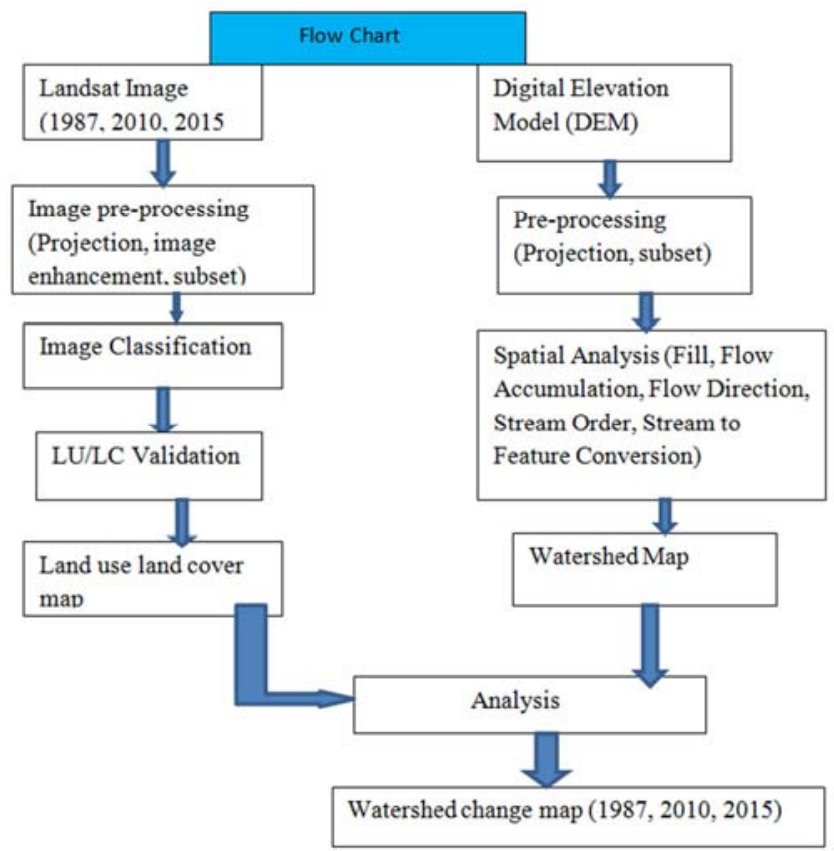

Figure 2. Flow Chart showed of LU/LC Analysis of the Study Area. 


\subsection{Data Analysis}

\subsubsection{Land Use and Land Cover Change Analysis}

The purpose of image classification in this study was to categories the pixels in the Landsat (path 169 row55 of 1987_TM 2010 and 2015_Landsat8) composite image into four land cover classes. The four land cover classes are cultivated land, grassland, forestland and shrub and bush land. Landsat (path 169 row55 of 1987_TM and 2015_Landsat8) data, Image processing, supervised classification, ground Verification, accuracy assessment, and output derivation are the main components involved in this study. By using the satellite image of the study area and by the help of software such as ERDAS Imagine for image processing and ARCGIS for digitizing and analysis, the current land use types of the study area was identified and mapped.

\subsubsection{Field Verification and Interpretation Accuracy}

The accuracy assessment is essentially a measure of how many ground truth pixels were classified correctly. In this study, accuracy assessment was done for the recent satellite image of Landsat (path 169 row55 of 1987 TM 2010 and 2015_Landsat8) for which the ground truth data is likely corresponding. An overall accuracy shows Bilbo watershed 1987 land use land cover accuracy assessment 88.93\%, 2010 land use land cover accuracy assessment $89.04 \%$ and 2015 accuracy assessment $91.33 \%$ and in Arujya watershed 1987 land use land cover accuracy assessment 88.56 \%, 2010 land use land cover accuracy assessment $89.43 \%$ and 2015 land use land cover accuracy assessment $90.94 \%$. The overall accuracy is related average with the accuracy of each class weighted by the proportion of test samples for that class in the total testing sets.

The evaluation of the field measurement was made on mean of slope classes, plots and structures using the one sample t-test and comparison with the recommended standard values. The quantitative data were analyzed using on sample t-test and descriptive statistics were used for the interpretation of the data.

\section{Results and Discussions}

\subsection{Evaluation of Soil Bund and Fanyajuu in Bilbo and Arujya Watersheds}

\subsubsection{Level Fanyajuu in Bilbo and Arujya Watershed}

The selected technical parameters for evaluation of level Fanyajuu in Bilbo and Arujya watersheds were good and poor performance. The selected technical parameters for evaluation were:- depth, width of ditch, lips/berms and spacing, height of embankment and top and bottom width of embankment.

\section{(i). Ditch Depth and Width of Level Fanyajuu}

The ditch width and depth were compared with recommended standard value of $0.6 \mathrm{~m}$ and $0.5 \mathrm{~m}$ [6]. The ditch depth and width of level fanya juu was used as technical parameters to evaluate fanya juu that measured during field visit is shown in Table 1.

Table 1. Ditch depth and width in meter mean and deviation.

\begin{tabular}{|c|c|c|c|c|c|c|c|c|}
\hline \multirow{2}{*}{ Slope Classes } & \multicolumn{2}{|c|}{ Ditch depth Bilbo } & \multicolumn{2}{|c|}{ Ditch depth Arujya } & \multicolumn{2}{|c|}{ Ditch width Bilbo } & \multicolumn{2}{|c|}{ Ditch width Arujya } \\
\hline & Mean & Deviation & Mean & Deviation & Mean & Deviation & Mean & Deviation \\
\hline$<5 \%$ & 0.58 & 0.08 & 0.50 & 0.00 & 0.46 & -0.14 & 0.53 & -0.07 \\
\hline $5-10 \%$ & 0.59 & 0.09 & 0.57 & 0.07 & 0.50 & -0.10 & 0.47 & -0.13 \\
\hline $10-15 \%$ & 0.62 & 0.12 & 0.57 & 0.07 & 0.58 & 0.02 & 0.50 & 0.10 \\
\hline $15-30 \%$ & - & - & 0.47 & 0.03 & - & - & 0.49 & -0.11 \\
\hline$>30 \%$ & - & - & 0.50 & 0.00 & - & - & 0.49 & -0.11 \\
\hline
\end{tabular}

In Bilbo watershed $<5 \%, 5-10 \%$ and $10-15 \%$ slope class ditch depth mean value were $0.58 \mathrm{~m}, 0.59 \mathrm{~m}$ and $0.62 \mathrm{~m}$ respectively. The statistical analysis showed that there was a significant difference observed between recommended ditch depth of structures and measured values in the Bilbo watershed. In Bilbo, ditch depth of fanyajuu structure was shallower than recommended value. In fact, the study area has high rainfall pattern during rainy season and therefore, the highest ditch depth is more advantageous in order to control the overtopping of the water. In Arujya watersheds $<5 \%$, 5$10 \%, 10-15 \%, 15-30 \%$ and $>30 \%$ slope class ditch depth mean value were $0.50 \mathrm{~m}, 0.57 \mathrm{~m}, 0.57 \mathrm{~m}, 0.47$ and 0.50 respectively. In Arujya watersheds the mean ditch depth at $<5$ and $>30 \%$ slope classes, the measured value for fanyajuu was agreed with recommended standard value $0.5 \mathrm{~m}$. The maximum ditch depth value was recorded at $10-15 \%$ slope class in Bilbo watersheds compared to standard value and in the Arujya watersheds minimum value recorded at $15-30 \%$ slope classes compared to recommended value. At all slopes, the value for fanyajuu at Arujya were in agreement with the standard value $(0.5 \mathrm{~m})$.

In Bilbo watershed at $<5 \%, 5-10 \%$ and $10-15 \%$ slope class ditch width mean values were $0.46 \mathrm{~m}, 0.50 \mathrm{~m}$ and $0.58 \mathrm{~m}$ respectively. In Arujya watershed at $<5 \%, 5-10 \%, 10-15 \%, 15-$ $30 \%$ and $>30 \%$ slope class ditch width mean values were $0.53 \mathrm{~m}, 0.47 \mathrm{~m}, 0.50 \mathrm{~m}, 0.49 \mathrm{~m}$ and $0.49 \mathrm{~m}$ respectively. The statistical analysis shown that, there was significant difference between the recommended and the measured value at Bilbo and Arujya watersheds. As the ditch width takes more farmland, the farmers could ignore technical considerations of structures and if ditch width became narrow, there could be break down of the structure due to the overflow of water flow. This idea also confirmed from the farmers and DA during transect walk.

\section{(ii). Lips/Berm and Spacing Between in Level Fanyajuu}

According to Lakew Desta et al. [6] the minimum recommend berm size of bund structure is $0.15 \mathrm{~m}$. The field measurement of spacing and lips/berm of level fanyajuu are 
given in Table 2.

Table 2. Spacing between fanyajuu and lip/berm fanyajuu in meter mean and deviation.

\begin{tabular}{llllllll}
\hline \multirow{2}{*}{ Slope Classes } & \multicolumn{2}{l}{ Spacing in Bilbo } & \multicolumn{2}{l}{ Spacing in Arujya } & \multicolumn{2}{l}{ Berm in Bilbo } \\
\cline { 2 - 7 } & Mean & Deviation & Mean & Deviation & Mean & Deviation & Mean \\
\hline$<5 \%$ & 18.83 & -1.22 & 19.50 & -0.52 & 0.19 & 0.04 & 0.20 \\
$5-10 \%$ & 19.87 & 5.84 & 18.83 & 4.74 & 0.15 & 0.00 & 0.03 \\
$10-15 \%$ & 18.33 & 6.18 & 10.33 & -1.82 & 0.15 & 0.00 & 0.00 \\
$15-30 \%$ & - & - & 9.666 & 0.42 & - & - & 0.15 \\
$>30 \%$ & - & - & 10.30 & 1.12 & - & - & 0.17 \\
\hline
\end{tabular}

In Bilbo watershed at $<5 \%, 5-10 \%$ and $10-15 \%$ slope class the mean spacing values were $18.83 \mathrm{~m}, 19.87 \mathrm{~m}$ and 18.33 respectively. The statistical analysis showed in Bilbo watershed at $<5 \%$ and $10-15 \%$ slope classes, the result shown that there was no significant difference was observed compared to standard value $(20 \mathrm{~m})$ [2] and in $10-15 \%$ slope class significant difference have observed as compared to recommended value $(14.06 \mathrm{~m})$ [2]. In this recommended value, the slope increase spacing is decrease. However, the result indicated the slope increases the spacing also increases.

In Arujya watershed $<5 \%, 5-10 \%, 10-15 \%, \quad 15-30 \%$ and $>30 \%$ slope class the mean spacing values were $19.50 \mathrm{~m}$, $18.83 \mathrm{~m}, 10.33 \mathrm{~m}, 9.67 \mathrm{~m}$ and $10.30 \mathrm{~m}$ respectively. The statistical analysis showed that the result were no significant difference as compared to recommended standard value $(20 \mathrm{~m}, 20 \mathrm{~m}, 14.04 \mathrm{~m}$ and $9.18 \mathrm{~m} \mathrm{[2]} \mathrm{and} \mathrm{in} 15-30 \%$ slope class the result indicated that there was a significant difference as compared to recommended standard value $(12.12 \mathrm{~m})$ [2]). As the spacing is too wide, an overtopping and erosion problem may occur and if the spacing is to narrow, there exist farmers complain for the unsuitability during farm operations. Therefore, that compromise should make between the technical recommendations of spacing in between two consecutives bund under different slope steepness classes as farmers said.
In Bilbo watershed at $<5 \%, 5-10 \%$ and $10-15 \%$ slope class the mean value lips/berm of level fanyajuu structure were $0.19 \mathrm{~m}, 0.15 \mathrm{~m}$ and $0.15 \mathrm{~m}$ respectively. In Arujya watershed at $<5 \%, 5-10 \%, 10-15 \% 30 \%$ and $>30 \%$ slope class the mean value lips/berm were $0.20 \mathrm{~m}, .15 \mathrm{~m}, 0.16 \mathrm{~m}, 0.17 \mathrm{~m}$ and $0.16 \mathrm{~m}$ respectively. The statistical analysis showed that there was no significance difference between the standard and measured value for the lip/berm in Bilbo and Arujya watersheds in all slope class.

\section{(iii). Embankment Height, Top and Bottom Width Fanyajuu}

The embankment height of level fanyajuu in Bilbo sub watershed at the $5-10 \%$ slope class, the result same to recommended standard value $(0.6 \mathrm{~m})$ [6] and at slope classes $<5 \%$ and $10-15 \%$ close to standard value. At Arujya watershed embankment height of level fanyajuu in $<5 \%, 10$ $15 \%$ and $15-30 \%$ slope class, the result same to recommended standard value and in $5-10 \%$ slope class close to recommended standard value and in $>30 \%$ slope in Arujya sub watersheds greater than standard recommended standard value (Table 3). The result of embankment height for the level fanyajuu structure indicated that, there is no significant differences between measured and recommended values for both watersheds.

Table 3. Embankment heights, top and bottom width of fanyajuu in meter mean and deviation.

\begin{tabular}{llllll}
\hline \multirow{2}{*}{ Slope Classes } & Height in Bilbo & & \multicolumn{2}{c}{ Height in Arujya } & \multicolumn{2}{c}{ Top width in Bilbo } \\
\cline { 2 - 6 } & Mean & Deviation & Mean & Deviation & Mean \\
\hline$<5 \%$ & 0.56 & -0.04 & 0.60 & 0.00 & 0.38 \\
$5-10 \%$ & 0.60 & 0.00 & 0.53 & -0.07 & 0.08 \\
$10-15 \%$ & 0.57 & -0.03 & 0.60 & 0.00 & 0.35 \\
$15-30 \%$ & & & 0.60 & 0.00 & 0.01 \\
$>30 \%$ & & & 0.64 & 0.04 & \\
\hline
\end{tabular}

Table 3. Continued.

\begin{tabular}{llllll}
\hline \multirow{2}{*}{ Slope Classes } & \multicolumn{2}{l}{ Top width in Arujya } & \multicolumn{2}{l}{ Bottom width in Bilbo } & \multicolumn{2}{c}{ Bottom width in Arujya } \\
\cline { 2 - 6 } & Mean & Deviation & Mean & Deviation & Mean \\
\hline$<5 \%$ & 0.30 & 0.00 & 1.13 & -0.27 & 1.33 \\
$5-10 \%$ & 0.31 & 0.01 & 1.50 & 0.1 & 1.33 \\
$10-15 \%$ & 0.33 & 0.03 & 1.13 & -0.27 & 1.16 \\
$15-30 \%$ & 0.38 & 0.08 & & -0.07 & 1.35 \\
$>30 \%$ & 0.32 & 0.02 & & -0.24 & 1.27 \\
\hline
\end{tabular}

The embankment top width of level fanyajuu in Bilbo watershed mean value at the $<5 \%, 5-10 \% \quad 10-15 \%$ slope classes were $0.38 \mathrm{~m}, 0.35 \mathrm{~m}$ and $0.31 \mathrm{~m}$ respectively (Table 3 ). The statistical analysis showed that there was no significant difference observed between the embankment top width recommended for level fanyajuu and the measured value in
Bilbo watersheds. In Arujya watersheds embankment top width of level fanyajuu mean value at $<5 \%, 5-10 \%, 10-15 \%$, $15-30 \%$ and $>30 \%$ slope classes, the result shown in table 3 were $0.30 \mathrm{~m}, 0.31 \mathrm{~m} 0.33 \mathrm{~m}, 0.38 \mathrm{~m}$ and $0.32 \mathrm{~m}$ and also in Arujya sub watersheds at $<5 \%$ slope the mean value were the same to recommended standard value $(0.3 \mathrm{~m})$ [6]. The 
statistical analysis showed that there was significant difference compared to recommended standard value. The top width embankment in Arujya of level fanyajuu is higher than the recommended value. It could take more farmland and farmers may not accept the technical advice given by the expert and if the top width embankment is significantly smaller than the standard value. It may be difficult to plant grass stabilizer in it.

In Bilbo Sub watershed $<5 \%, 5-10 \%$ and $10-15 \%$ slope classes, the embankment of bottom width mean were $1.13 \mathrm{~m}$, $1.50 \mathrm{~m}$ and $1.13 \mathrm{~m}$ respectively. In Arujya watershed at $<5 \%$, $5-10 \%$ and $10-15 \%, 15-30 \%$ and $>30 \%$ slope classes, the embankment of bottom width mean were $1.33 \mathrm{~m}, 1.33 \mathrm{~m}$ and $1.16 \mathrm{~m}, 1.35 \mathrm{~m}$ and $1.27 \mathrm{~m}$ respectively. The statistical analysis showed that there was no significant difference compared to recommended standard.

\subsubsection{Level Soil Bund in Bilbo and Arujya Watershed}

\section{(i). Depth and Width of Ditch Level Soil Bund}

The ditch width and depth were compared with recommended standard value of $0.6 \mathrm{~m}$ and $0.5 \mathrm{~m}$ respectively [6]. Ditch depth and width of level soil bund were used as technical parameters to evaluate soil bund.

Table 4. Ditch depth and width of soil bund in meter mean and deviation.

\begin{tabular}{llllllll}
\hline \multirow{2}{*}{ Slope Classes } & \multicolumn{2}{l}{ Ditch depth Bilbo } & \multicolumn{2}{l}{ Ditch depth Arujya } & \multicolumn{2}{l}{ Ditch width Bilbo } \\
\cline { 2 - 7 } & Mean & Deviation & Mean & Deviation & Mean & Deviation & Mean \\
\hline$<5 \%$ & 0.57 & 0.07 & 0.53 & 0.03 & 0.45 & -0.15 & 0.55 \\
$5-10 \%$ & 0.53 & 0.03 & 0.52 & 0.02 & 0.56 & -0.04 & -0.05 \\
$10-15 \%$ & 0.58 & 0.08 & 0.56 & 0.06 & 0.55 & -0.05 & -0.08 \\
$15-30 \%$ & - & - & 0.53 & 0.03 & - & - & -0.64 \\
$>30 \%$ & - & - & 0.56 & 0.06 & - & -0.04 & 0.46 \\
\hline
\end{tabular}

In Bilbo watershed at $<5 \%, 5-10 \%$ and $10-15 \%$ slope classes, the mean value ditch depth of level soil bund structure were $0.57 \mathrm{~m}, 0.53 \mathrm{~m}$ and $0.58 \mathrm{~m}$ respectively. At Arujya watershed in $<5 \%, 5-10 \%, 10-15 \%, \quad 15-30 \%$ and $>30 \%$ slope classes, the mean value ditch depth of level soil bund structure were $0.53 \mathrm{~m}, 0.52 \mathrm{~m}, 0.56 \mathrm{~m}, 0.53 \mathrm{~m}$ and $0.56 \mathrm{~m}$ respectively. The statistical analysis showed that there was a significant difference observed between recommended ditch depth of soil bund structures and measured values in Bilbo and Arujya sub watershed. Therefore, the ditch depth of level soil bund structure is significantly less than the recommended for study area. This variation may be due to the soil, climate and farming system is the same across the study area. In the study area, there is high rainfall pattern throughout the season and therefore the highest depth of ditch is more advantageous in order to control the overtopping of the water.

At Bilbo watershed in $<5 \%$ and $5-10 \%$ slope class ditch width of level soil bund mean values were $0.45 \mathrm{~m}$ and $0.56 \mathrm{~m}$ and also in the $10-15 \%$ slope class in Bilbo watershed is $0.55 \mathrm{~m}$. In Arujya watershed at $<5 \%$ slope and $5-10 \%$ slope classes ditch width of level soil bund mean values were $0.55 \mathrm{~m}$ and $0.68 \mathrm{~m}$. In $10-15 \%$ slope classes the mean value was $0.64 \mathrm{~m}$. In $15-30 \%$ and $>30 \%$ slope classes at Arujyaa watersheds ditch width mean values were $0.46 \mathrm{~m}$ and $0.51 \mathrm{~m}$. The statistical analysis shown that there was significant variation in all slope class between the recommended value for ditch width of level soil bund and the measured value at Bilbo watershed. The ditch width of the structure in Bilbo sub watersheds was found comparatively less than the recommended standard value. As the ditch width takes more farmland, the farmers could ignore technical considerations of structures and if ditch width became narrow, there could be break down of the structure due to the force of water flow. This idea also confirmed by the farmers and DA during transect walk. The statistical analysis showed that there was no significant difference between the standard and measured value for the ditch width at Arujya watershed in all slope classes.

\section{(ii). Lips/Berm and Spacing Between in Level Soil Bund}

The spacing recommended in the study of Daniel D [2] is given in result and spacing is decided by discussing with individual farmer in the plot [6]. The field measurement of spacing and lips/berm of level soil bund are given result.

Table 5. Spacing between soil bund and lip/berm soil bund in meter mean and deviation.

\begin{tabular}{|c|c|c|c|c|c|c|c|c|}
\hline \multirow{2}{*}{ Slope Classes } & \multicolumn{2}{|c|}{ Spacing in Bilbo } & \multicolumn{2}{|c|}{ Spacing in Arujya } & \multicolumn{2}{|c|}{ Berm in Bilbo } & \multicolumn{2}{|c|}{ Berm in Arujya } \\
\hline & Mean & Deviation & Mean & Deviation & Mean & Deviation & Mean & Deviation \\
\hline$<5 \%$ & 18.8 & -1.20 & 19.3 & -0.7 & 0.19 & 0.04 & 0.15 & 0.00 \\
\hline $5-10 \%$ & 19.8 & 9.8 & 17.8 & 7.8 & 0.15 & 0.00 & 0.13 & -0.02 \\
\hline $10-15 \%$ & 18.0 & 10.0 & 17.3 & 9.8 & 0.16 & 0.01 & 0.15 & 0.00 \\
\hline $15-30 \%$ & - & - & 16.6 & 9.6 & - & - & 0.20 & 0.05 \\
\hline$>30 \%$ & - & - & 9.33 & 2.33 & - & - & 0.15 & 0.00 \\
\hline
\end{tabular}

In Bilbo watershed in $<5 \%, 5-10 \%, 10-15 \%$ slope class the mean spacing values were $18.8 \mathrm{~m}, 19.8 \mathrm{~m}, 18.0 \mathrm{~m}$ respectively. The statistical analysis shown in Bilbo watershed spacing in $<5 \%$ slope class the result indicate no significant difference observed compared to recommended value and in $5-10 \%$ and $10-15 \%$ slope classes there was a significant variation as compared to recommended standard value observed.

In Arujya watershed at $<5 \%, 5-10 \%, 10-15 \%, 15-30 \%$ 
and $>30 \%$ slope class the mean spacing values were $19.3 \mathrm{~m}$, $19.8 \mathrm{~m}, 17.3 \mathrm{~m}, 16.6 \mathrm{~m}$ and $9.33 \mathrm{~m}$ respectively. In this recommended value the slope increase spacing is decrease and the result indicate the slope increases the spacing not decreases. In Arujya watershed the statistical analysis was shown at $<5 \%$ slope class no significant difference was observed to compared to standard value (20m) [2] and in 5$10 \%, 10-15 \%, 15-30 \%$ and $>30 \%$ slope classes had a significant difference observed compared to recommended standard value (10m, $7 \mathrm{~m}$ and $6 \mathrm{~m}$ ) [2]. As the spacing is too wide, an overtopping and erosion problem may occur and if the spacing is to narrow, there exist farmers complain for the unsuitability during farm operations.

In the $<5 \%, 5-10 \%$ and $10-15 \%$ slope classes, the mean value lips/berm of level soil bund structure were $0.19 \mathrm{~m}$, $0.15 \mathrm{~m}$ and $0.16 \mathrm{~m}$ respectively. At Arujya watershed in $<5 \%$, $5-10 \%, 10-15 \%, 15-30 \%$ and $>30 \%$ slope classes, the mean value lips/berm of level soil bund structure were $0.15 \mathrm{~m}$,
$0.13 \mathrm{~m}, 0.15 \mathrm{~m}, 0.20 \mathrm{~m}$ and $0.15 \mathrm{~m}$ respectively. The statistical analysis showed that there was significant difference observed between the measured and recommended [6] at Bilbo watershed. The statistical analysis shown in the Arujya sub watersheds, there was no significant difference between the recommended and measured value of lips/berm at $95 \%$ of significance.

\section{(iii). Embankment Height, Top and Bottom Width of Level Soil Bund}

The results of embankment height for the selected plots of level soil bund in all slope class are indicated in Table 6 . The results of level soil bund structure were compared with the recommended bund height standard value [6]. According to Lakew Desta et al. [6], the results of top and bottom width of embankment were compared with the top and bottom width of embankment recommended standard value of $0.3 \mathrm{~m}$ and $1.4 \mathrm{~m}$.

Table 6. Embankment heights, top and bottom width of soil bund in meter mean and deviation.

\begin{tabular}{llllll}
\hline \multirow{2}{*}{ Slope Classes } & Height in Bilbo & & Height in Arujya & \multicolumn{2}{c}{ Top width in Bilbo } \\
\cline { 2 - 6 } & Mean & Deviation & Mean & Deviation & Mean \\
\hline$<5 \%$ & 0.55 & -0.05 & 0.61 & 0.01 & 0.33 \\
$5-10 \%$ & 0.48 & -0.12 & 0.58 & -0.05 & 0.40 \\
$10-15 \%$ & 0.58 & -0.92 & 0.60 & 0.00 & 0.30 \\
$15-30 \%$ & & & 0.60 & 0.00 & 0.10 \\
$>30 \%$ & & & 0.56 & -0.04 & \\
\hline
\end{tabular}

Table 6. Continued.

\begin{tabular}{llllll}
\hline \multirow{2}{*}{ Slope Classes } & \multicolumn{2}{l}{ Top width in Arujya } & \multicolumn{2}{l}{ Bottom width in Bilbo } & \multicolumn{2}{c}{ Bottom width in Arujya } \\
\cline { 2 - 6 } & Mean & Deviation & Mean & Deviation & Mean \\
\hline$<5 \%$ & 0.35 & 0.05 & 1.23 & -0.17 & 1.40 \\
$5-10 \%$ & 0.31 & 0.01 & 1.33 & -0.07 & 1.36 \\
$10-15 \%$ & 0.31 & 0.01 & 1.13 & -0.27 & 1.40 \\
$15-30 \%$ & 0.35 & 0.05 & & 0.00 & 1.16 \\
$>30 \%$ & 0.31 & 0.01 & & -0.24 & 1.33 \\
\hline
\end{tabular}

In Bilbo watershed at $<5 \%, 5-10 \%$ and $10-15 \%$ and slope classes the mean values were $0.55 \mathrm{~m}, 0.48 \mathrm{~m}$ and $0.58 \mathrm{~m}$ respectively. In Arujya watershed the mean values at $<5 \%, 5$ $10 \%, 10-15 \%, 15-30 \%$ and $>30 \%$. Slope classes were $0.61 \mathrm{~m}$ and $0.58 \mathrm{~m}, 0.60 \mathrm{~m}, 0.60 \mathrm{~m}$ at and $0.56 \mathrm{~m}$ respectively. The statistical analysis showed that there was significant difference observed in Bilbo watersheds compared to recommended value and no significant difference observed in Arujya watershed between the embankment height recommended $(0.6 \mathrm{~m})$ value [6] for level soil bund and the measured value in Arujya sub watersheds.

The embankment top width of level soil bund in Bilbo watershed mean value at $<5 \%$ and $5-10 \%$ slope classes, the result shown in Table 6 were $0.33 \mathrm{~m}$ and $0.40 \mathrm{~m}$. In the mean of $10-15 \%$ slope class close to standard value in Bilbo watershed, embankment top width of level soil bund is $0.30 \mathrm{~m}$. At the Arujya watersheds the embankment top width of level soil bund mean value at the $<5 \%$ and $5-10 \%$ slope classes, the result shown in Table 6 were $0.35 \mathrm{~m}$ and $0.31 \mathrm{~m}$. In the $10-15 \%$ slope class the mean close to standard value in Arujya watershed, embankment top width of level soil bund are $0.31 \mathrm{~m}$. In the embankment top width of level soil bund in Arujya watersheds at $15-30 \%$ and $>30 \%$ slope classes, the mean values were $0.35 \mathrm{~m}$ and $0.31 \mathrm{~m}$. Generally, in all slope classes, the mean values of embankment top width are close to recommended standard value.

The statistical analysis showed that there is no significant difference observed between the embankment top width recommended for level soil bund and the measured value in Bilbo sub watersheds and also in Arujya watershed very significant variation observed compared to recommended standard value $(0.3 \mathrm{~m})$ [6]. If the top width embankment in Arujya of level soil bund is higher than the recommended value, it could take more farmland and farmers may not accept the technical advice given by the expert and if the top width embankment is significantly smaller than the standard value. It may be difficult to plant grass stabilizer on it.

At Bilbo watershed in $<5 \%$ slope class, the embankment bottom width mean are $1.23 \mathrm{~m}$. In $5-10 \%$ and $10-15 \%$ slope classes, the embankment bottom width mean values were in both slope class were $1.33 \mathrm{~m}$ and $1.13 \mathrm{~m}$ respectively. In Arujya watershed at $<5 \%$ slope class, the embankment 
bottom width mean are $1.40 \mathrm{~m}$. In $5-10 \%$ and $10-15 \%$ slope classes, embankment bottom width mean values were $1.36 \mathrm{~m}$ and $1.40 \mathrm{~m}$ respectively. In $15-30 \%$ and $>30 \%$ classes, the embankment bottom width mean values in Arujya watersheds were $1.16 \mathrm{~m}$ and $1.33 \mathrm{~m}$ respectively. At all slope classes, the values for soil bund at Arujya and Bilbo watershed were in agreement with the recommended value.

\subsection{The Change in Land Use and Land Cover in Bilbo and Arujya Watershed Using Remote Sensing Image}

\subsubsection{Land Covers Change in Bilbo Watersheds Between 1987-2015}

The land cover of the area are categorized into four major categories cultivated land, grass lands, forest lands (both natural and plantation) and bush and shrub land (Table 7).
Table 7 indicates, in 1987 cultivated lands constitutes about $58.6 \%$ (136.1 ha) of the total area, while shrubs and bush, and forest land comprise about 11.02\% (25.6 ha) and $24.5 \%$ (57.3 ha) respectively. In 1987, cultivated land was the dominant land cover, with $58.6 \%$ of the total area. The shares of grassland have decreased from $5.72 \%$ in 1987 to $0.96 \%$ in 2010 , and forestland had increased to $35.72 \%$ in 2010. Plantations appeared as a new land cover to add to the forestland cover. They might have changed from grassland cover to plantation cover. On the 2015 image, the shares of forestland have decreased from $35.72 \%$ in 2010 to $0.70 \%$ and grass cover increased from $0.96 \%$ in 2010 to $17.75 \%$ in 2015. However, forest cover was decreased and cultivated lands covered $83.94 \%$ of the area in 2010 and decreased to $78.64 \%$ in 2015 . The change in the land cover of an area during the period is shown in Figure 3 below.

Table 7. Land cover classes and their respective percentage and area covered in Bilbo watershed.

\begin{tabular}{|c|c|c|c|c|c|c|}
\hline \multirow{2}{*}{ Land Use classes } & \multicolumn{2}{|l|}{1987} & \multicolumn{2}{|l|}{2010} & \multicolumn{2}{|l|}{2015} \\
\hline & $(\%)$ & Area (ha) & $\%$ & Area (ha) & $\%$ & Area (ha) \\
\hline Grassland & 5.72 & 13.3 & 0.96 & 2.24 & 17.75 & 41.24 \\
\hline Shrub and bush land & 11.02 & 25.6 & 9.97 & 23.13 & 2.90 & 6.74 \\
\hline Cultivated land & 58.6 & 136.1 & 83.94 & 195.01 & 78.64 & 182.7 \\
\hline Forest land & 24.5 & 57.3 & 35.72 & 83 & 0.70 & 1.64 \\
\hline Total & 100 & 232.3 & 100 & 232.3 & 100 & 232.3 \\
\hline
\end{tabular}

BILBO WATERSHED CHANGE DETECTION MAP
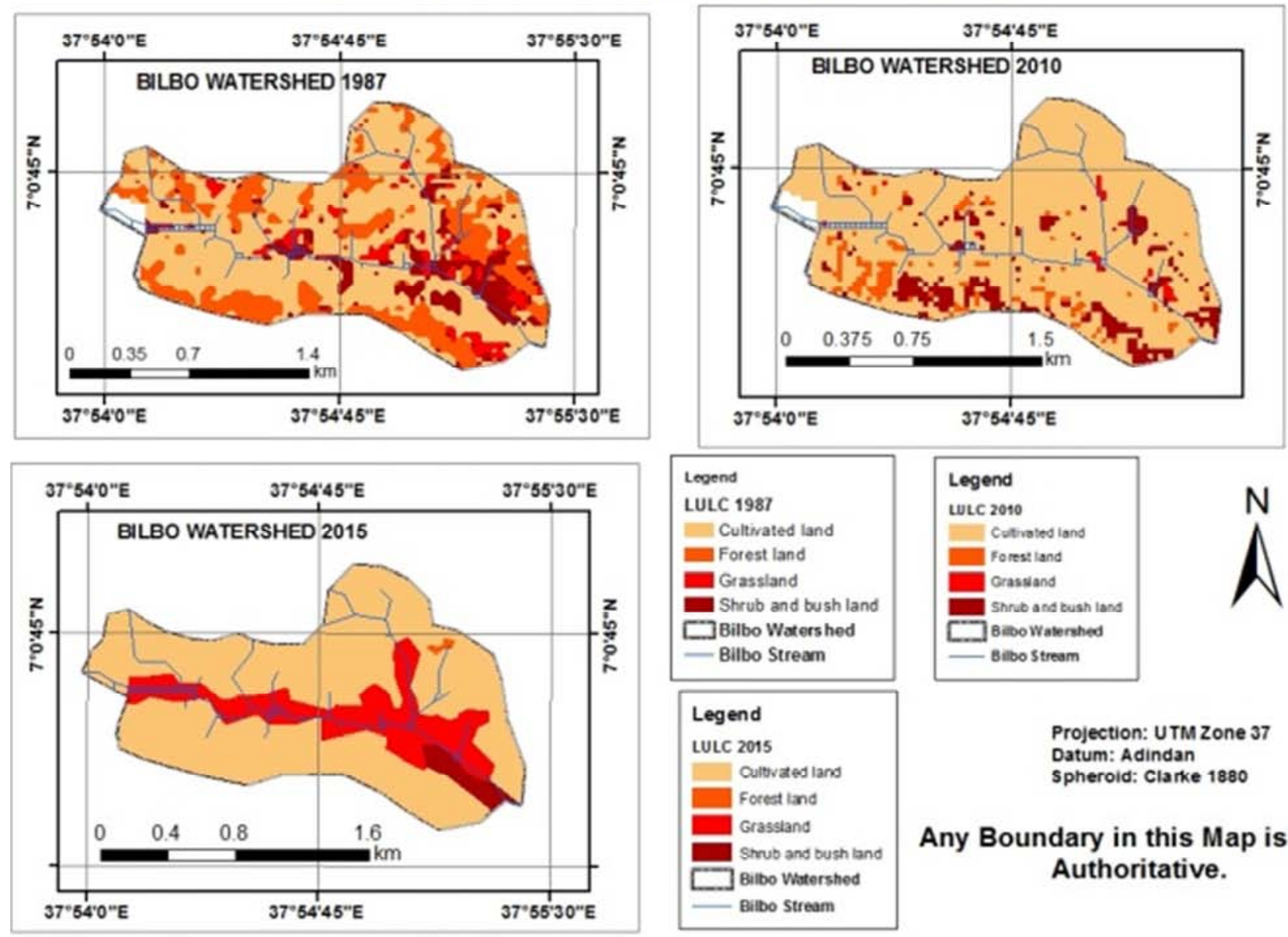

Any Boundary in this Map is NOT Authoritative.

Figure 3. Land Cover Map of the study area in 1987, 2010 and 2015. 
Table 8. Change of land cover change in percentage between 1987, 2010 and 2015.

\begin{tabular}{lll}
\hline Land Use classes & Change 2010-1987 (\%) & Change 2015-2010 (\%) \\
\hline Grassland & -4.76 & 16.79 \\
Shrub and bush land & -1.05 & -7.07 \\
Cultivated land & 25.34 & -5.3 \\
Forest land & 11.22 & -35.02 \\
\hline
\end{tabular}

\subsubsection{Land Cover Dynamics Between 1987, 2010 and 2015 in Bilbo Watershed}

The analysis of the 1987, 2010 and 2015 data revealed considerable land use land cover change as a response to the vegetation restoration intervention. The land use land cover $(\mathrm{Lu} / \mathrm{Lc})$ change in the current study shows remarkable variation in the different $\mathrm{Lu} / \mathrm{Lc}$ type. The data is summarized in Table 8. Forest cover was increased by $11.22 \%$ from 1987 to 2010. This is the attributable to a forestation program of the derge regime and the forestland represents new enclosure with rehabilitation. Grassland cover decreased by $4.76 \%$ between 1987 and 2010, and then increased from 2010 to 2015. Cultivated land decreased by 5.3\% between 2010 and 2015 . Similarly, forest land decreased by $35.02 \%$. In the same period, the rate of shrubs and bushes decreased by $7.07 \%$.

Four major land cover types were identified through satellite image for the specified years of 1987, 2010 and 2015 (Figure 3). Forest cover increased by $11.22 \%$ between 1987 and 2010. It can be concluded that the destruction of shrub and bushes was the direct result of a forestation program. Similarly, Woldeamlak B. et al. [10] reported that, in Chemoga Watershed Blue Nile basin of the area under forest cover increased by 19\% between 1957 and 1982 (7 ha/y). Between 2010 and 2015, the forest cover declined 35.02\% resulting in a removal of 81.36 ha. Thus, the destruction of forest vegetation may be attributed to an increase in the demand for fuel wood and construction materials for the surrounding town. Similarly, Sharma et al. (2007) reported that, the natural forest shown the highest decrease of $20 \%$ in Mamlay Watershed (India) from 1988 to 1997. In contrast to this finding, Woldeamlak B. et al. [10] reported that, the forest coverage was increased by $27 \%$ between the period of 1982 and 1998; this is attributable to the forestation program of the derge regime an initiative to preserve indigenous trees or forest and planting of trees at the household level in the area of Chemoga Watershed. Cultivated land increased by $25.34 \%$ between 2010 and 1987. Kahsay Berhe [5] reported that, in the central high land of Ethiopia, cultivated land increased from $25 \%$ to $56.4 \%$ between $1971 / 72$ and 2000 . Similarly Gete Z [4] reported a significant increase in cultivated land between 1958 and 1995 in the Dembecha woreda of Amhara Region, North Ethiopia. These studies indicated that population pressure was the cause for the expansion of cultivation land. As a result, more land was needed for these activities. In contrast, the study made by Belay Tegene [1] reported that, the increment of cropland was insignificant in the Derekolli catchment of south Wollo between 1957 and 2000 .

\subsubsection{Land Covers Change in Arujya Watersheds Between 1987-2015}

Land cover change is the major area investigated to understand the land use dynamics, change in natural resource cover and distribution. The land cover of the area are categorized into four major categories:- cultivated land, grass lands, forest lands (both natural and plantation) and bush and shrub land (Table 9).

Table 9. Land cover classes and their respective percentage and area covered in Arujya watershed.

\begin{tabular}{|c|c|c|c|c|c|c|}
\hline \multirow{2}{*}{ Land Use classes } & \multicolumn{2}{|l|}{1987} & \multicolumn{2}{|l|}{2010} & \multicolumn{2}{|l|}{2015} \\
\hline & $(\%)$ & Area (ha) & $\%$ & Area (ha) & $\%$ & Area (ha) \\
\hline Grassland & 3.03 & 2.91 & 0.91 & 0.88 & - & - \\
\hline Shrub and bush land & 2.69 & 2.58 & 2.28 & 2.19 & - & - \\
\hline Cultivated land & 93.7 & 89.79 & 96.6 & 92.65 & 100 & 95.85 \\
\hline Forest land & 0.59 & 0.57 & 0.13 & 0.13 & - & - \\
\hline Total & 100 & 95.85 & 100 & 95.85 & 100 & 95.85 \\
\hline
\end{tabular}

As indicated in Table 9, in 1987 cultivated lands constitutes about $93.7 \% \%$ (89.79 ha) of the total area, while shrubs and bush, and forestland comprise about $2.69 \%(2.58$ ha) and $0.59 \%$ ( 0.57 ha) respectively. In 2010 , cultivated land was the dominant land cover, with $96.6 \%$ of the total area. They might have changed from grass and forestland cover to cultivated land. The shares of grassland have decreased from $3.03 \%$ in 1987 to $0.91 \%$, and forestland had decreased to $0.13 \%$. On the 2015 image, cultivated cover increased from $96.9 \%$ to $100 \%$. However cultivated lands dominated by expansion of agricultural purpose. The change in the land cover of an area during the period is shown in figure 4 below. Land covers dynamics between 1987, 2010 and 2015 in Arujya watershed.

Land cover was mapped and measured for the years 1987 , 2010 and 2015 . Forest cover was decreased by $0.46 \%$ from 1987 to 2010 (Table 10). Shrub and bush land cover decreased by $0.41 \%$ between 1987 and 2010. Cultivated land increased by $3.4 \%$ between 2010 and 2015 (Table 10). Similarly, forest land decreased by $0.13 \%$. (Table 10 ). In the same period, the rate of shrubs and bushes decreased by $2.58 \%$ (Table 10$)$. 
ARUJA WATERSHED CHANGE DETECTION MAP
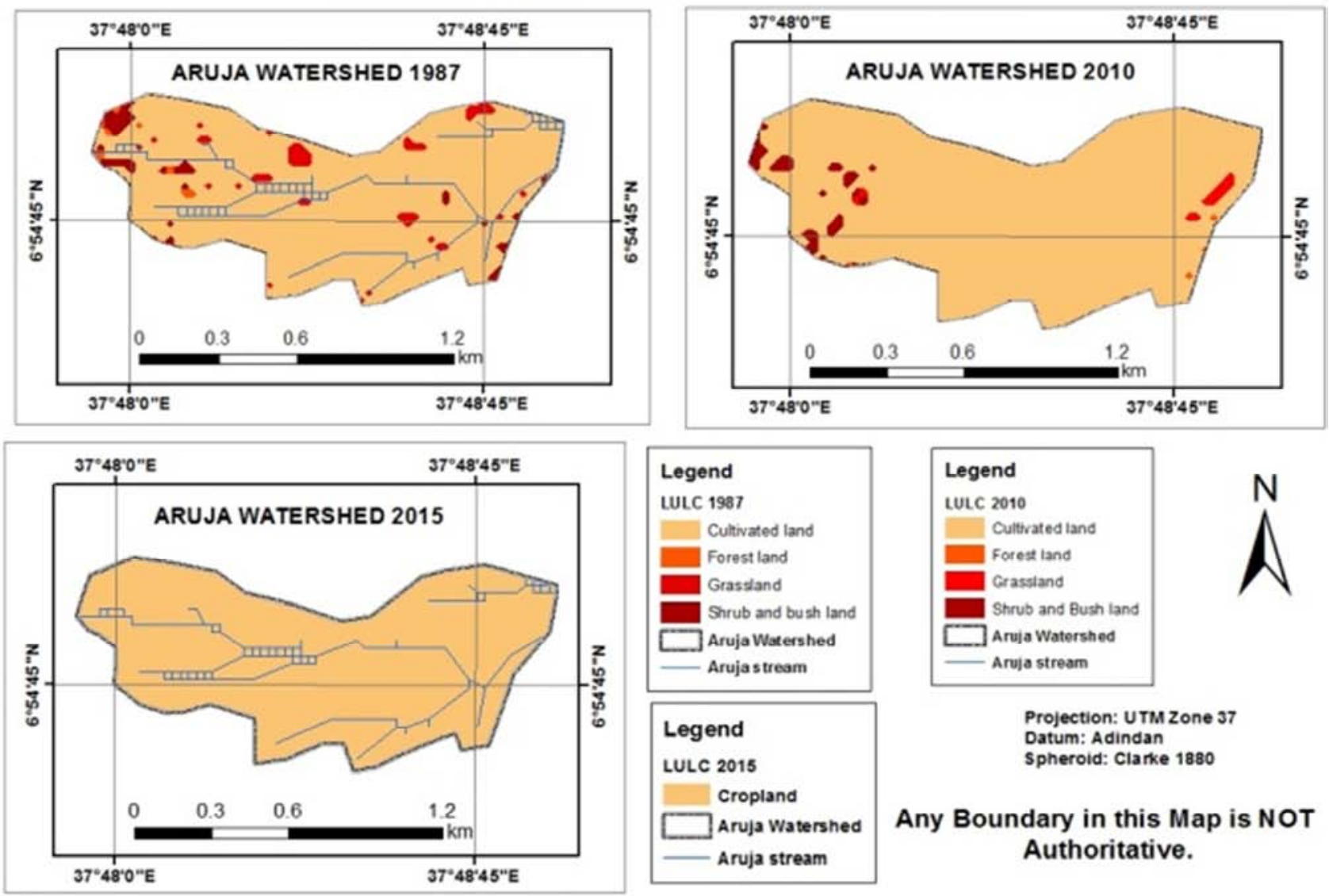

Projection: UTM Zone 37

Datum: Adindan

Spheroid: Clarke 1880

Any Boundary in this Map is NOT Authoritative.

Figure 4. Land Cover Map of the study area in 1987, 2010 and 2015.

Table 10. Change of land cover change in percentage between 1987, 2010 and 2015 .

\begin{tabular}{lll}
\hline Land Use classes & Change 2010-1987 (\%) & Change 2015-2010 (\%) \\
\hline Grassland & -2.12 & -0.91 \\
Shrub and bush land & -0.41 & -2.58 \\
Cultivated land & 2.9 & 3.4 \\
Forest land & -0.46 & -0.12 \\
\hline
\end{tabular}

The main land cover change was the clearance of shrub and bush and grassland that took place between 2010 and 2015. The cultivated land cover was increased because of the expansion of population and mainly at the expense of shrub and bush cover. Kashay (2004) reported that, in the central high land of Ethiopia, cultivated land increased from $25 \%$ to $56.4 \%$ between $1971 / 72$ and 2000 . Similarly, Gete Z [4] reported a significant increase in cultivated land between 1958 and 1995 in the Dembecha woreda Amhara Region, North Ethiopia. These studies indicated that population pressure was the cause for the expansion of cultivation land. As a result, more land was needed for these activities. In contrast, the study made by Belay Tegene [1] reported that the increment of crop land was insignificant in the Derekolli catchment of south Wollo between 1957 and 2000. He noted that, there was no significant change observed on the expansion of cultivated land due to population increment.

\section{Conclusion and Recommendation}

Land degradation problem is the most dominant in the study area. Farmers in Bilbo and Arujya watersheds practiced soil and water conservation measures (soil bund and fanyajuu) to minimize the problem of soil erosion. However, for fanyajuu, in Bilbo watershed at 10-15\% slope classes and in Arujya sub watershed at $15-30 \%$ slope class spacing is larger than recommended ones. In Bilbo watershed ditch depth record minimum than recommended one and in both watershed ditch width is also minimum than recommended one. As the ditch width takes more farmland and farmers not take in to account of technical design and in this case the flow of water break down the structure. In top width of embankment at Arujya watershed is less than recommended one. In level soil bund, spacing is maximum than recommended one in Bilbo watershed at 5-10\% slope class and $10-15 \%$ slope class and in Arujya watershed except $<5 \%$ slope in other slope class maximum value recorded than recommended one and the ditch depth is minimum value recorded than recommended one in both watersheds. In Bilbo, sub watershed ditch width, berm/lips and embankment heights lower than recommended one and in Arujya watershed top width of embankment lower than recommended one. 
The majority of farmers had created good awareness in identifying major causes of erosion problem based on land use type and slope steepness and the use of different soil and water conservation measures, which are important in preventing soil erosion. In community based soil and water conservation practice, development campaign different phase applied. These area: - planning, implementing and monitoring and evaluation. In planning phase, in Bilbo watershed $21.7 \%$ of farmers are not involved in watershed problem identification, $26 \%$ are not know criteria applied in identifying and prioritized watershed problems and in Arujya watershed $6.6 \%$ to $16.6 \%$ are not involved. In Bilbo and Arujya watersheds $(21.7 \%$ to $16.6 \%)$ and $(21.7$ to $10 \%)$ farmers are not knew how technology are chosen and not took training. In implementation phase, in Bilbo watershed given target was not set.

The study area of land cover trend was observed in Bilbo watershed decreasing grass land and bush and shrub land between 1987 and 2010. Whereas, increase the cover of cultivated and forest land. At 2010 and 2015 shrub and bush land, cultivated land and forestland decreased. Whereas, increase grassland. In Arujya watershed grassland, forestland and shrub and bush land decreased in between 1987 and 2010. Whereas, increased grassland. In Arujya watersheds decreasing grassland, shrub and bush land and forest land between 2010 and 2015. Whereas, increase the cover of cultivated land. In the future work in the areas of fanyajuu construction in the both watershed some improvement should be made regarding spacing, ditch depth and width, embankment of height for both watersheds and will be maintained with the recommended range. It is recommended that the future development activities will use these technological resources more, for better management of the area's natural resources.

\section{Conflict of Interests}

The authors declare that they have no competing interests.

\section{Acknowledgements}

I would like to acknowledge Woreda Agricultural Bureau for giving chance to pursue my Master program. In addition,
I would like to acknowledge Development agents and friends for helping during data collection.

\section{References}

[1] Belay Tegene. 2002. Land cover/ use changes in the Derekolli catchment of the South Welo Zone Of Amhara Region, Ethiopia. Eastern Africa Social Science Research Review 18 (1): $1-20$.

[2] Daniel D, (2001). Soil and water conservation guideline, natural resources management sector, Minister of agriculture and rural development, Addis Ababa, Ethiopia pp 23.

[3] Eyasu, E. (2002). Farmers' perceptions of soil fertility change and management. Addis Ababa, Ethiopia: SOS Sahel Ethiopia and Institute for Sustainable Development.

[4] Gete Z (2000). Landscape dynamics and soil erosion process modeling in the north-western Ethiopian highlands. African Studies Series A16. Berne: Geographica Bernensia.

[5] Kahsay Berhe. 2004. Land Use and Land Cover Changes in the Central Highlands of Ethiopia: The case of yerer mountain and its surroundings. MSc Thesis, Addis Ababa University, Ethiopia.

[6] Lakew Desta, Carucci, V., Asrat Wendemagenehu and yitayew Abebe (eds)., (2005). Community based participatory watershed development: A Guideline. Ministry of Agriculture and rural development, Addis Ababa, Ethiopia pp 69-188.

[7] Merkineh., M., (2011): Farmers' views of soil erosion hazards and decision on conservation Practices: the case of mount damota sub watershed, south Ethiopia pp 31.

[8] Solomon Abate 1994. Land-use dynamics, soil degradation and potential for sustainable use in Metu area, Illubabor Region, Ethiopia. African series A13. University of Berne, Berne, Switzerland.

[9] Tesfaye, B., (2003). Understanding farmers: Explaining soil and water conservation in Konso, Wolaita and wello, Ethiopia: PHD Dissertation, wegeningen university, the Netherlands pp 15-17.

[10] Woldeamlak B., Sterk G., 2002. Farmers' participation in Soiland Water conservation Activities in the Chemoga watershed, Blue Nile basin, Ethiopia. Land Degrad. Develop. $13,189-200$. 